\title{
Deoxidation Equilibrium of Manganese and Silicon in Liquid Iron-Nickel Alloys
}

\author{
V. Ya. DASHEVSKII, A. M. KATSNELSON, N. N. MAKAROVA, K. V. GRIGOROVITCH and V. I. KASHIN
}

Baikov Institute of Metallurgy and Material Science, Russian Academy of Sciences, Leninskii prosp., 49, Moscow-119991, Russia.

(Received on February 26, 2002; accepted in final form on May 5, 2003)

\begin{abstract}
The thermodynamic analysis of oxygen solutions in Fe-Ni melts containing manganese and silicon has been carried out. The deoxidation power of manganese essentially increases with the nickel content in melt. The solubility curves pass through a minimum, which shifts to lower manganese contents, as nickel content in melt increases. For alloys containing more than 50-60\% nickel, the minimal oxygen concentrations are obtained at manganese content equal to $1-1.5 \%$, the further increase of manganese concentration results in an increase of oxygen content. Silicon deoxidation power also increases with the increase of nickel content in melt, but not so sharply as in the case of manganese. In the range of silicon contents considered, no minimum was observed in oxygen solubility curves. Thermodynamics of oxygen, manganese and silicon solutions in the $\mathrm{Fe}-40 \% \mathrm{Ni}$ melts has been studied experimentally in a temperature range of 1823-1923 K. With temperature drop, deoxidation power of both manganese and silicon increases. In the $\mathrm{Fe}-40 \% \mathrm{Ni}$ melts in both cases it is higher than in iron but lower than in nickel. Dependence of oxygen concentration on manganese and silicon contents is expressed by empirical equations. Upon combined deoxidation with manganese and silicon, it is possible to obtain lower oxygen concentrations in metal, in comparison with separate deoxidation due to decreased activities of manganese oxide and silica.
\end{abstract}

KEY WORDS: deoxidation equilibrium; manganese; silicon; iron-nickel melts; thermodynamic analysis; experimental study.

\section{Introduction}

The Fe-Ni alloys are widely used in modern engineering and are, in particular, the basis of a large group of special alloys. It is known that oxygen is a harmful impurity in these alloys. Deoxidizing elements used upon alloy production allow one to obtain the final metal with low oxygen content and small amount of nonmetallic inclusions. Manganese and silicon are most often used as deoxidizing elements. Available thermodynamic data on the oxygen solutions in liquid iron ${ }^{1,2)}$ and nickel ${ }^{1,3)}$ are useful to estimate the oxygen solubility in the $\mathrm{Fe}-\mathrm{Ni}$ melts ${ }^{4)}$ as well as effect of manganese and silicon on the oxygen solubility.

This study presents analytical and experimental investigations on the thermodynamics of oxygen solutions in the $\mathrm{Fe}-\mathrm{Ni}$ melts containing manganese and silicon.

\section{Thermodynamic Consideration}

Reaction of deoxidizing elements $\mathrm{R}$ with oxygen in the Fe-Ni melt:

$$
\begin{gathered}
\mathrm{R}_{m} \mathrm{O}_{n}(1, \mathrm{~s})=m[\mathrm{R}]+n[\mathrm{O}] \\
K_{\mathrm{R}}=\frac{\left([\% \mathrm{R}] \cdot f_{\mathrm{R}}\right)^{m}\left([\% \mathrm{O}] \cdot f_{\mathrm{O}}\right)^{n}}{X_{\mathrm{R}_{m} \mathrm{O}_{n}} \gamma_{\mathrm{R}_{m} \mathrm{O}_{n}}}
\end{gathered}
$$

where $X_{i}$ is mole fraction, $f_{i}$ and $\gamma_{i}$ is the activity coefficient of element $i$ in mass percent base and mole fraction base, respectively, can be written as the sum of reactions:

$$
\begin{aligned}
& \mathrm{R}_{m} \mathrm{O}_{n}(1, \mathrm{~s})=m \mathrm{R}(1, \mathrm{~s})+\frac{n}{2} \mathrm{O}_{2}(\mathrm{~g}) \\
& \mathrm{R}(1, \mathrm{~s})=[\mathrm{R}]_{1 \%(\mathrm{Fe}-\mathrm{Ni})} \\
& \Delta G_{(3)}^{\circ}=R T \ln \left(\gamma_{\mathrm{R}(\mathrm{Fe}-\mathrm{Ni})}^{\circ} M_{\mathrm{Fe}-\mathrm{Ni}} / M_{\mathrm{R}} \cdot 100\right) \\
& \frac{1}{2} \mathrm{O}_{2}(\mathrm{~g})=[\mathrm{O}]_{1 \%(\mathrm{Fe}-\mathrm{Ni})} \\
& \Delta G_{(4)}^{\circ}=R T \ln \left(\gamma_{\mathrm{O}(\mathrm{Fe}-\mathrm{Ni})}^{\circ} M_{\mathrm{Fe}-\mathrm{Ni}} / M_{\mathrm{O}} \cdot 100\right)
\end{aligned}
$$

where $\gamma_{i}^{\circ}$ denotes the activity coefficient of element $i$ in infinite dilution, and $M_{i}$ denotes the molecular mass of element $i$.

From Gibbs energy of reaction (1):

$$
\Delta G_{(1)}^{\circ}=\Delta G_{(2)}^{\circ}+m \Delta G_{(4)}^{\circ}+n \Delta G_{(4)}^{\circ}
$$

it is possible to calculate the equilibrium constant of reaction (1):

$$
\ln K_{\mathrm{R}}=-\Delta G_{(1)}^{\circ} / R T
$$

The concentration of oxygen, which is in equilibrium with $\mathrm{R}$, at a given $\mathrm{R}$ content can be calculated by the equation: 
ISIJ International, Vol. 43 (2003), No. 10

Table 1. Equilibrium constants for reaction (1), activity coefficients and interaction parameters for in the Fe-Ni melts at $1873 \mathrm{~K}$.

\begin{tabular}{|c|c|c|c|c|c|c|}
\hline \multirow{2}{*}{ Parameter } & \multicolumn{6}{|c|}{$\mathrm{Ni}, \%$} \\
\hline & 0 & 25 & 40 & 50 & 75 & 100 \\
\hline $\log K_{\mathrm{Mn}}$ & $-1.274^{2)}$ & -1.622 & -1.807 & -1.974 & -2.495 & -3.104 \\
\hline $\log K_{\mathrm{Si}}$ & $-4.676^{2)}$ & -4.899 & -5.049 & -5.174 & -5.654 & $-6.542^{6)}$ \\
\hline$\gamma_{O}^{\circ}$ & $0.0105^{9)}$ & 0.0168 & 0.0254 & 0.0355 & 0.0984 & $0.357^{9)}$ \\
\hline$\gamma_{\mathrm{Mn}}^{\circ}$ & $1.44^{2)}$ & 1.132 & 1.130 & 1.175 & 1.372 & $1.50^{10)}$ \\
\hline$\gamma_{\mathrm{Si}}^{\circ}$ & $0.0013^{2)}$ & 0.00091 & 0.00055 & 0.00037 & 0.00014 & $0.00009^{6)}$ \\
\hline$e_{\mathrm{O}}^{\mathrm{O}}$ & $-0.17^{2)}$ & -0.132 & -0.110 & -0.092 & -0.052 & $0^{3)}$ \\
\hline$e_{\mathrm{Mn}}^{\mathrm{Mn}}$ & $0^{2)}$ & 0.00139 & 0.00226 & 0.00285 & 0.00439 & $0.006^{1)}$ \\
\hline$e_{\mathrm{O}}^{\mathrm{Mn}}$ & $-0.021^{2)}$ & -0.121 & -0.182 & -0.226 & -0.318 & $-0.45^{3)}$ \\
\hline$e_{\mathrm{Mn}}^{\mathrm{O}}$ & $-0.083^{2)}$ & -0.426 & -0.637 & -0.787 & -1.103 & $-1.53^{3)}$ \\
\hline$e_{\mathrm{Si}}^{\mathrm{Si}}$ & $0.103^{2)}$ & 0.123 & 0.136 & 0.144 & 0.167 & $0.19^{6)}$ \\
\hline$e_{\mathrm{O}}^{\mathrm{Si}}$ & $-0.066^{2)}$ & -0.066 & -0.066 & -0.065 & -0.065 & $-0.065^{6)}$ \\
\hline$e_{\mathrm{Si}}^{\mathrm{O}}$ & $-0.119^{2)}$ & -0.117 & -0.116 & -0.115 & -0.112 & $-0.110^{6)}$ \\
\hline
\end{tabular}

$$
\begin{aligned}
& \log [\% \mathrm{O}]_{\mathrm{Fe}-\mathrm{Ni}}=(1 / n)\left\{\log K_{\mathrm{R}}+\log X_{\mathrm{R}_{m} \mathrm{O}_{n}}+\log \gamma_{\mathrm{R}_{m} \mathrm{O}_{n}}\right. \\
& -m \log [\% \mathrm{R}]_{(\mathrm{Fe}-\mathrm{Ni})}-\left[m e_{\mathrm{R}(\mathrm{Fe}-\mathrm{Ni})}^{\mathrm{R}}+n e_{\mathrm{O}(\mathrm{Fe}-\mathrm{Ni})}^{\mathrm{R}}\right][\% \mathrm{R}]_{(\mathrm{Fe}-\mathrm{Ni})} \\
& \left.-\left[n e_{\mathrm{O}(\mathrm{Fe}-\mathrm{Ni})}^{\mathrm{O}}+m e_{\mathrm{R}(\mathrm{Fe}-\mathrm{Ni})}^{\mathrm{O}}\right][\% \mathrm{O}]_{(\mathrm{Fe}-\mathrm{Ni})}\right\}
\end{aligned}
$$

where $e_{i}^{j}$ denotes the interaction parameters when the component concentrations are expressed as mass percents.

The value $[\% \mathrm{O}]_{(\mathrm{Fe}-\mathrm{Ni})}$ in the right-hand part of Eq. (7) can be expressed through the ratio $\left(K_{\mathrm{R}} /[\% \mathrm{R}]^{m}\right)^{1 / n}$, assuming that $X_{\mathrm{R}_{m} \mathrm{O}_{n}} \approx 1, \gamma_{\mathrm{R}_{m} \mathrm{O}_{n}} \approx 1, f_{\mathrm{R}} \approx 1$, and $f_{\mathrm{O}} \approx 1$ in Eq. (1a). This substitution does not result in appreciable error because of small value $[\% \mathrm{O}]_{(\mathrm{Fe}-\mathrm{Ni})}$. This Eq. (7) takes the form:

$$
\begin{aligned}
\log [\% \mathrm{O}]_{\mathrm{Fe}-\mathrm{Ni}}=(1 / n)\left\{\log K_{\mathrm{R}}+\log X_{\mathrm{R}_{m} \mathrm{O}_{n}}+\gamma_{\mathrm{R}_{m} \mathrm{O}_{n}}\right. \\
\quad-m \log [\% \mathrm{R}]_{(\mathrm{Fe}-\mathrm{Ni})}-\left[m e_{\mathrm{R}(\mathrm{Fe}-\mathrm{Ni})}^{\mathrm{R}}+n e_{\mathrm{O}(\mathrm{Fe}-\mathrm{Ni})}^{\mathrm{R}}\right][\% \mathrm{R}]_{(\mathrm{Fe}-\mathrm{Ni})} \\
\left.-\left[n e_{\mathrm{O}(\mathrm{Fe}-\mathrm{Ni})}^{\mathrm{O}}+m e_{\mathrm{R}(\mathrm{Fe}-\mathrm{Ni})}^{\mathrm{O}}\right]\left(K_{\mathrm{R}} /[\% \mathrm{R}]^{m}\right)^{1 / n}\right\} \ldots \ldots \ldots \ldots \ldots . . . . . . . . . .
\end{aligned}
$$

The Gibbs energies, J/mol, for reaction (2) are quoted from the published data ${ }^{5)}$ :

$$
\begin{gathered}
\Delta G_{(2)}^{\circ}(\mathrm{MnO})=401263-84.32 T ; \\
\Delta G_{(2)}^{\circ}\left(\mathrm{SiO}_{2}\right)=906442-175.85 T
\end{gathered}
$$

For iron the reference literature ${ }^{2)}$ gives the values of the equilibrium constants of reaction (1) for the deoxidation of this melt with manganese and silicon:

$$
\begin{gathered}
\log K_{\mathrm{Mn}(\mathrm{Fe})}=-14880 / T+6.67 ; \\
\log K_{\mathrm{Si}(\mathrm{Fe})}=-30110 / T+11.40
\end{gathered}
$$

For nickel the equilibrium constant of reaction (1) is given for the melts deoxidized with silicon as follows:

$$
\log K_{\mathrm{Si}(\mathrm{Ni})}=-15680 / T+1.83^{6)}
$$

In other cases the values of the equilibrium constant of reaction (1) for $\mathrm{Fe}-\mathrm{Ni}$ melts are calculated according to the scheme described above (Eqs. (2)-(6)).

The molecular mass for the Fe-Ni melts was calculated by the formula:

$$
M_{\mathrm{Fe}-\mathrm{Ni}}=M_{\mathrm{Fe}} X_{\mathrm{Fe}}+M_{\mathrm{Ni}} X_{\mathrm{Ni}}
$$

Based on a subregular model, the activity coefficients in dilute solution range $\gamma_{\mathrm{R}(\mathrm{Fe}-\mathrm{Ni})}^{\circ}$ and $\gamma_{\mathrm{O}(\mathrm{Fe}-\mathrm{Ni})}^{\circ}$ are represented by the following equation ${ }^{7}$ :

$$
\begin{aligned}
& \ln \gamma_{i(\mathrm{Fe}-\mathrm{Ni})}^{\circ}=X_{\mathrm{Fe}} \ln \gamma_{i(\mathrm{Fe})}^{\circ}+X_{\mathrm{Ni}} \ln \gamma_{i(\mathrm{Ni})}^{\circ} \\
& +X_{\mathrm{Fe}} X_{\mathrm{Ni}}\left[X_{\mathrm{Ni}}\left(\ln \gamma_{i(\mathrm{Ni})}^{\circ}-\ln \gamma_{i(\mathrm{Fe})}^{\circ}+\varepsilon_{i(\mathrm{Ni})}^{\mathrm{Fe}}\right)\right. \\
& \left.+X_{\mathrm{Fe}}\left(\ln \gamma_{i(\mathrm{Fe})}^{\circ}-\ln \gamma_{i(\mathrm{Ni})}^{\circ}+\varepsilon_{i(\mathrm{Fe})}^{\mathrm{Ni}}\right)\right]
\end{aligned}
$$

where $\varepsilon_{i}$ denotes the interaction parameters in mole fraction base.

The activity coefficients for iron and nickel are given in Table 1. Interaction parameters used in calculations were the following: $e_{\mathrm{Mn}(\mathrm{Fe})}^{\mathrm{Ni}}=-0.0072^{2)} ; e_{\mathrm{Si}(\mathrm{Fe})}^{\mathrm{Ni}}=0.001^{6)} ; e_{\mathrm{Si}(\mathrm{Ni})}^{\mathrm{Ni}}=$ $0^{6)} ; e_{\mathrm{O}(\mathrm{Fe})}^{\mathrm{Ni}}=0.006^{8)} ; e_{\mathrm{O}(\mathrm{Ni})}^{\mathrm{Fe}}=0.025 .^{8)}$ The $e_{\mathrm{Mn}(\mathrm{Ni})}^{\mathrm{Fe}}$ parameter was assumed to be zero similar to $e_{\mathrm{Si}(\mathrm{Ni})}^{\mathrm{Fe}}$ because of absence of experimental data. The results of calculations are listed in Table 1.

Dependence of calculated values of the equilibrium constant for reaction (1) on the content of deoxidizing agent and nickel in the $\mathrm{Fe}-\mathrm{Ni}$ melt deoxidized with manganese and silicon at $1873 \mathrm{~K}$ is represented in Table 1 and Fig. 1. The equilibrium constants are given for the reaction of deoxidizer with one atom of oxygen dissolved in melt, this allows one to more conveniently compare the above relationships. As is seen from the given data, the equilibrium constant of reaction (1) in both cases decreases with an increase in the nickel content in melt, which indicates an increase in the deoxidation power of both silicon and manganese. With manganese, the degree of this increase is much larger than that with silicon. 


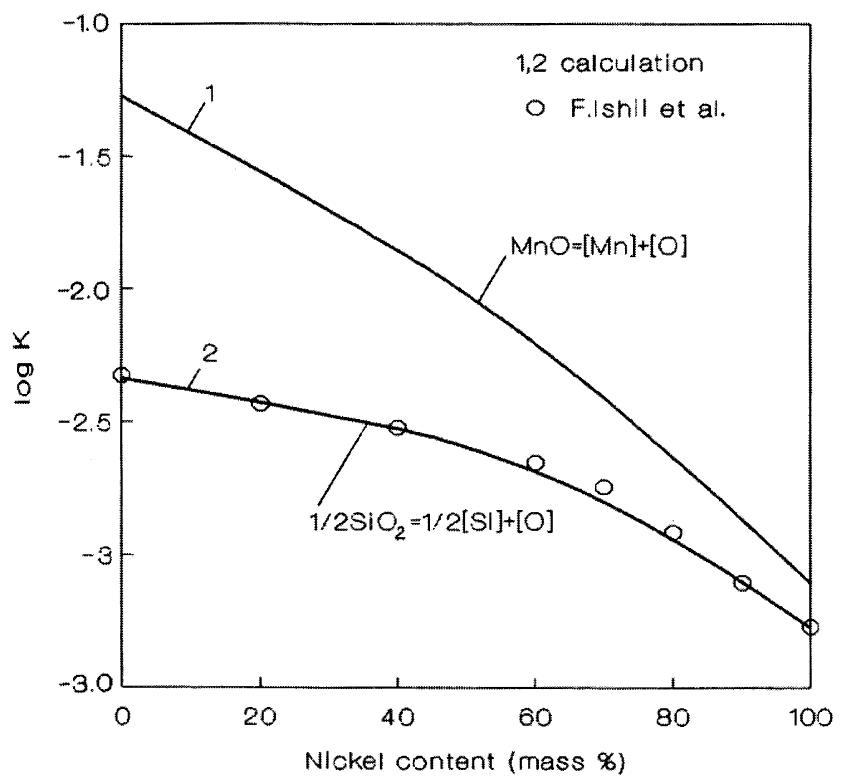

Fig. 1. Dependence of the equilibrium constant of reaction (1) on $\mathrm{Ni}$ content for deoxidation of Fe-Ni melts at $1873 \mathrm{~K}$.

The interaction parameters for different melts (Table 1) are estimated from the following assumption:

$$
\varepsilon_{i(\mathrm{Fe}-\mathrm{Ni})}^{j}=\varepsilon_{i(\mathrm{Fe})}^{j} X_{\mathrm{Fe}}+\varepsilon_{i(\mathrm{Ni})}^{j} X_{\mathrm{Ni}}
$$

In case of the deoxidation of iron-based melt with silicon and the residual silicon content in melt above $0.0022 \%$, an oxide phase contains only $\mathrm{SiO}_{2},{ }^{1)}$ and $a_{\mathrm{SiO}_{2}}=X_{\mathrm{SiO}_{2}}=1$. In the nickel-based melt, the silicon content in the presence of only $\mathrm{SiO}_{2}$ is quite low, since nickel is characterized by the less affinity to oxygen in comparison with iron.

When iron-nickel melts are deoxidized with manganese, the oxide phase, in addition to $\mathrm{MnO}$, also contains $\mathrm{FeO}$ and $\mathrm{NiO}$. Therefore, it is necessary to consider the following reactions $^{10)}$.

$$
\begin{aligned}
& \mathrm{Mn}(\mathrm{l})+\mathrm{FeO}(\mathrm{l})=\mathrm{MnO}(\mathrm{s})+\mathrm{Fe}(1) \\
& \Delta G_{(11)}^{\circ}=-91614 \mathrm{~J} / \mathrm{mol}, \quad K_{(11)}=357.81 \text { at } 1873 \mathrm{~K} \text {; } \\
& \mathrm{Mn}(\mathrm{l})+\mathrm{NiO}(\mathrm{s})=\mathrm{MnO}(\mathrm{s})+\mathrm{Ni}(\mathrm{l}) \\
& \Delta G_{(12)}^{\circ}=-168751 \mathrm{~J} / \mathrm{mol}, \quad K_{(12)}=50682.9 \text { at } 1873 \mathrm{~K}
\end{aligned}
$$

In the $\mathrm{FeO}-\mathrm{MnO}$ system, the continuous series of solutions is observed both in the liquid and solid states ${ }^{11)}$; however, there are no published data on the $\mathrm{NiO}-\mathrm{MnO}$ phase diagram. Therefore, based on the FeO-MnO phase diagram, as the first approximation, we assume that the oxide phase formed upon deoxidation of iron-nickel melts with manganese is the perfect solution $\left(\gamma_{\mathrm{MnO}}=1, \gamma_{\mathrm{FeO}}=1\right.$, $\left.\gamma_{\mathrm{NiO}}=1\right)$. The manganese solutions in the iron-nickel melts are characterized by slight positive deviations from the ideality (Table 1) and the dependence of the manganese activity coefficient on its concentration in liquid iron at $1843 \mathrm{~K}$ can be described ${ }^{12)}$ by the expression $\lg \gamma_{\mathrm{Mn}}=$ $\lg \gamma_{\mathrm{Mn}}^{\circ}\left(1-X_{\mathrm{Mn}}\right)^{2}$; therefore, it can be assumed that, at the low manganese contents $\left(X_{\mathrm{Mn}} \leq 0.03\right), \gamma_{\mathrm{Fe}} \approx 1, \quad \gamma_{\mathrm{Ni}} \approx 1$, $\gamma_{\mathrm{Mn}} \approx \gamma_{\mathrm{Mn}}^{\circ}$ for the iron-nickel melt. In this case, the following equations may be written:

$$
\frac{X_{\mathrm{MnO}}}{X_{\mathrm{FeO}}}=\frac{K_{(11)} \gamma_{\mathrm{Mn}(\mathrm{Fe}-\mathrm{Ni})}^{\circ} X_{\mathrm{Mn}}}{X_{\mathrm{Fe}}}
$$

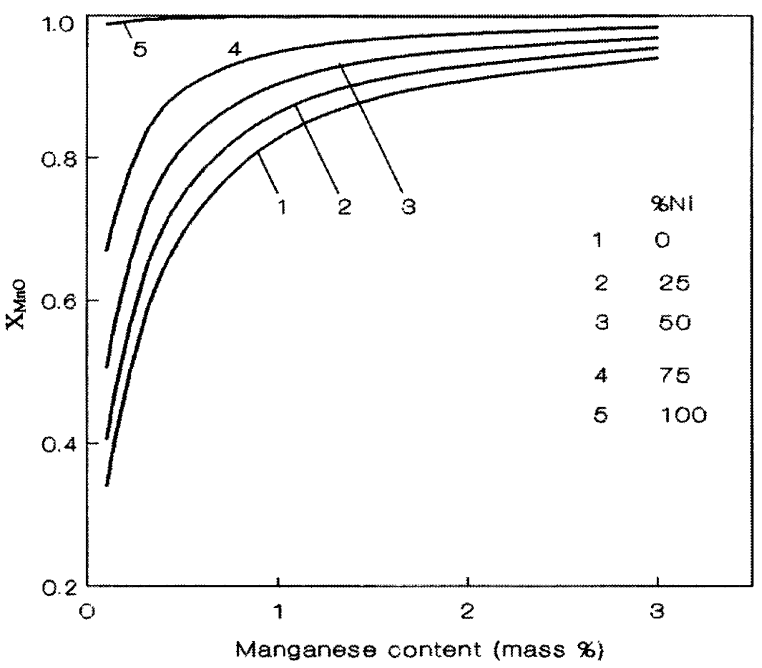

Fig. 2. Dependence of $\mathrm{MnO}$ mole fraction in oxide phase on $\mathrm{Mn}$ and Ni contents in melt at $1873 \mathrm{~K}$.

$$
\begin{aligned}
& \frac{X_{\mathrm{MnO}}}{X_{\mathrm{NiO}}}=\frac{K_{(12)} \gamma_{\mathrm{Mn}(\mathrm{Fe}-\mathrm{Ni})}^{\circ} X_{\mathrm{Mn}}}{X_{\mathrm{Fe}}} \\
& X_{\mathrm{MnO}}+X_{\mathrm{FeO}}+X_{\mathrm{NiO}}=1
\end{aligned}
$$

A mole fraction of $\mathrm{MnO}$ in the oxide phase can be calculated by these three equations. The dependence of $\mathrm{MnO}$ mole fraction in the oxide phase on the contents of manganese and nickel in a melt ${ }^{10)}$ is shown in Fig. 2. In ironbased melt, the $\mathrm{MnO}$ mole fraction in the oxide phase reaches to $0.3-0.5$ at the low manganese content $(<0.2 \%)$. With increasing nickel and manganese contents in melt, the mole fraction of $\mathrm{MnO}$ in oxide phase increases also. For pure nickel, it approaches unity, i.e. practically the oxide phase consists of manganese oxide.

The dependence of equilibrium oxygen concentration estimated by Eq. (7a) on the contents of manganese and silicon in the Fe-Ni melts at $1873 \mathrm{~K}$ is given in Fig. 3. From the given data one can see that the manganese deoxidation power considerably increases with the increase of nickel content in melt (Fig. 3(a)). The oxygen solubility curves pass through the minimum, which shifts to the lower manganese content with increase of nickel content in melt. For alloys containing more than $50 \%$ of nickel, the minimum oxygen concentrations are observed at the manganese content equal to $1-1.5 \%$. The deoxidation power of silicon also increases with the increase of nickel content in melt (Fig. 3(b)). In considered range of silicon content no minimum was observed as seen from the oxygen solubility curves.

\section{Experimental}

Deoxidation of $\mathrm{Fe}-\mathrm{Ni}$ melts with manganese and silicon (separately or together) has been studied experimentally by using $\mathrm{Fe}-40 \% \mathrm{Ni}$ alloy in a wide range of temperatures and concentrations of deoxidizing agent. The experiments have been carried out in an induction furnace fed by an $10 \mathrm{kV} \cdot \mathrm{A}$ HF generator. Carbonyl iron (99.99\%), electrolytic nickel (99.99\%), electrolytic manganese $(99.99 \%)$ and crystalline silicon $(99.999 \%)$ were used as a charge. The metal was melted in the $\mathrm{Ar}-\mathrm{H}_{2}$ atmosphere at temperatures of $1823-$ 

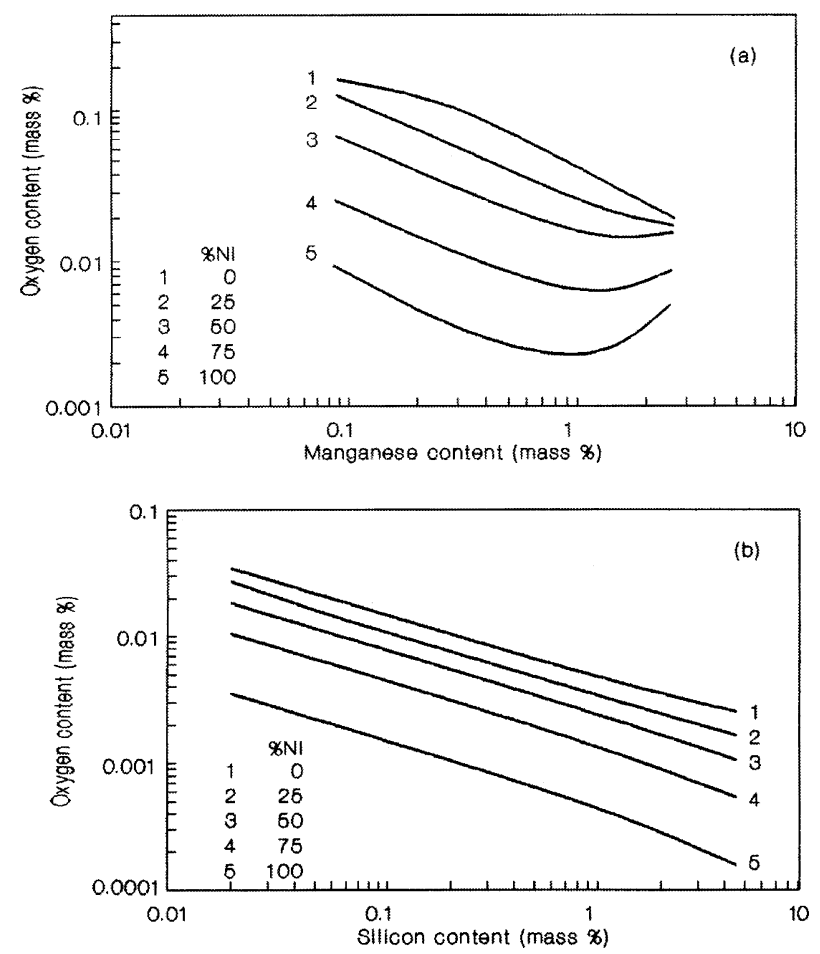

Fig. 3. Dependence of oxygen content in the Fe-Ni melts on the content of $\mathrm{Mn}(\mathrm{a}), \mathrm{Si}(\mathrm{b})$, and $\mathrm{Ni}$ at $1873 \mathrm{~K}$.

$1923 \mathrm{~K}$ in an alumina crucible in the case of manganese or manganese-silicon deoxidation and in a quartz crucible in the case of silicon deoxidation. Deoxidizing agents $(\mathrm{Mn}$, $\mathrm{Si}$ ) were introduced into the melt without breaking the furnace air-tightness; then this melt was held at a given temperature until equilibrium in Ar atmosphere. The temperature was measured by $\mathrm{Pt}-6 \% \mathrm{Ph} / \mathrm{Pt}-30 \% \mathrm{Ph}$ thermocouple. Equilibrium being achieved, a sample was taken from the melt and analyzed for nickel, manganese and silicon. The oxygen concentration was determined by inert gas fusioninfrared absorptiometry.

\section{Results and Discussion}

\subsection{Deoxidation with Manganese}

The experimental results are shown in Fig. 4(a) as compared to the calculated lines. As is seen from the experimental data points, the manganese deoxidation power considerably increases with the temperature drop. Oxygen solubility curves pass through a minimum, which shifts to the lower manganese contents when temperature drops. Experimental values of the equilibrium oxygen concentration for the $\mathrm{Fe}-40 \% \mathrm{Ni}$ alloy at $1873 \mathrm{~K}$ are lie below the calculated lines. The distinctions between experimental and calculated data may be attributed to the fact that oxide phase contained small amounts of $\mathrm{Al}_{2} \mathrm{O}_{3}$ along with $\mathrm{MnO}$, $\mathrm{FeO}$, and $\mathrm{NiO}$, owing to reactions of oxide phase with alumina crucible used in these experiments.

Dependence of oxygen concentration and value of $\log K_{\mathrm{Mn}}^{\prime}\left(K_{\mathrm{Mn}}^{\prime}=[\% \mathrm{Mn}][\% \mathrm{O}]\right)$ on the manganese content and temperature can be described by the following empirical equations:

\section{$1823 \mathrm{~K} ; \quad 0.21-2.50 \% \mathrm{Mn}$}

$$
\log [\% \mathrm{O}]=-2.49+0.18[\% \mathrm{Mn}]-0.68 \log [\% \mathrm{Mn}]
$$
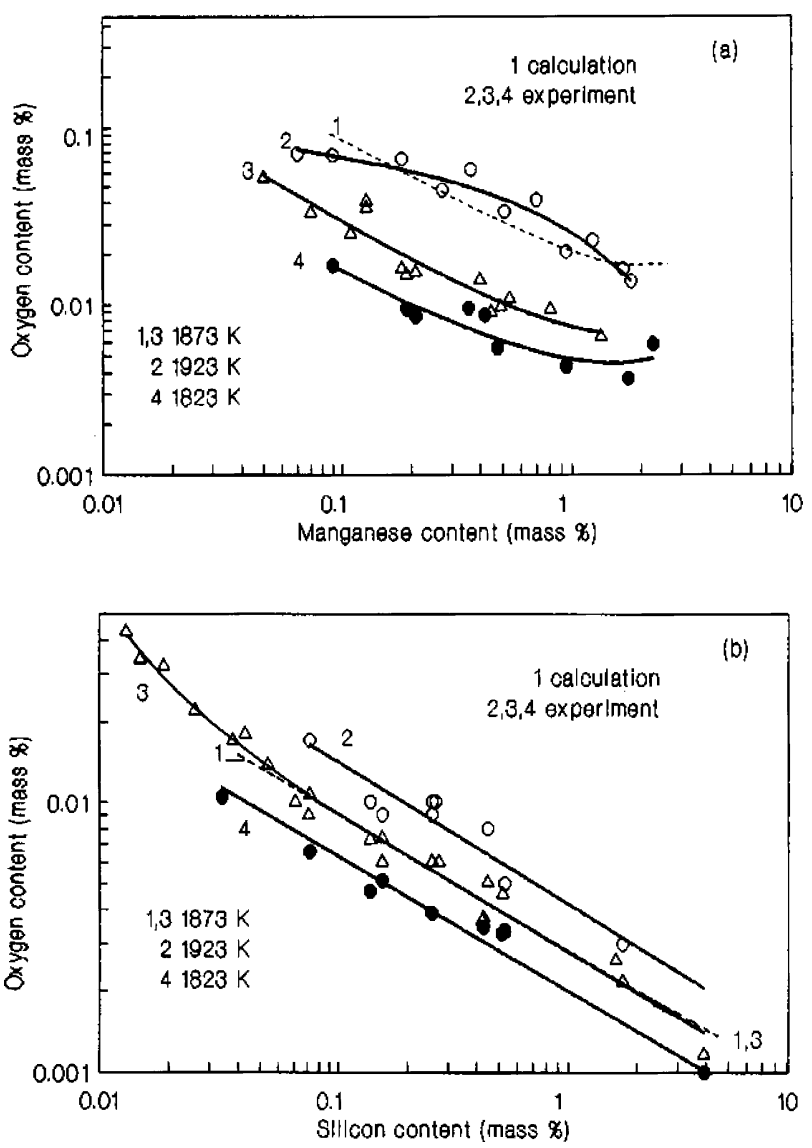

Fig. 4. Dependence of oxygen content in $\mathrm{Fe}-40 \%$ melts on the contents of $\mathrm{Mn}$ (a) and $\mathrm{Si}$ (b).

$$
\log K_{\mathrm{Mn}}^{\prime}=-2.25+0.68 \log [\% \mathrm{Mn}]
$$

$1873 \mathrm{~K} ; \quad 0.05-1.47 \% \mathrm{Mn}$

$$
\begin{aligned}
& \log [\% \mathrm{O}]=-2.26+0.14[\% \mathrm{Mn}]-0.76 \log [\% \mathrm{Mn}] \\
& \log K_{\mathrm{Mn}}^{\prime}=-2.13+0.35 \log [\% \mathrm{Mn}]
\end{aligned}
$$

$1923 \mathrm{~K} ; \quad 0.07-1.99 \% \mathrm{Mn}$

$$
\begin{aligned}
& \log [\% \mathrm{O}]=-1.18-0.26[\% \mathrm{Mn}]-0.18 \log [\% \mathrm{Mn}] \ldots \\
& \log K_{\mathrm{Mn}}^{\prime}=-1.59+0.48 \log [\% \mathrm{Mn}]
\end{aligned}
$$

\subsection{Deoxidation with Silicon}

The experimental results are given in Fig. 4(b) as compared to the estimated data. As is seen from the given data, the silicon deoxidation power considerably increases with the temperature drop. Dependence of oxygen concentration and value of $\log K_{\mathrm{Si}}^{\prime}\left(K_{\mathrm{Si}}^{\prime}=[\% \mathrm{Si}][\% \mathrm{O}]\right)$ on the silicon content in melt and the temperature within the range of silicon concentrations considered can be described by the following empirical equations:

$$
\begin{aligned}
1823 \mathrm{~K} ; & 0.08-4.30 \% \mathrm{Si} \\
& \log [\% \mathrm{O}]=-2.67-0.50 \log [\% \mathrm{Si}] \\
& \log K_{\mathrm{Si}}^{\prime}=-5.32+0.037 \log [\% \mathrm{Si}]
\end{aligned}
$$

$1873 \mathrm{~K} ; \quad 0.08-4.30 \% \mathrm{Si}$

$$
\begin{aligned}
& \log [\% \mathrm{O}]=-2.53-0.51 \log [\% \mathrm{Si}] \\
& \log K_{\mathrm{Si}^{\prime}}^{\prime}=-5.03+0.026 \log [\% \mathrm{Si}]
\end{aligned}
$$


$1923 \mathrm{~K} ; \quad 0.08-1.90 \% \mathrm{Si}$

$$
\begin{aligned}
& \log [\% \mathrm{O}]=-2.35-0.52 \log [\% \mathrm{Si}] \\
& \log K_{\mathrm{Si}}^{\prime}=-4.65+0.075 \log [\% \mathrm{Si}]
\end{aligned}
$$

The experiments have been carried out to study the deoxidation of the $\mathrm{Fe}-40 \% \mathrm{Ni}$ with silicon at its low contents $(0.009-0.08 \%)$ at $1873 \mathrm{~K}$. Data obtained are plotted in Fig. 4(b). The experimental finding that relationship between oxygen and silicon contents is not linear at $[\mathrm{Si}]<0.05 \%$ suggests the presence of iron-nickel silicates (Fe, Ni)O $\mathrm{SiO}_{2}$ as reaction products at such silicon concentrations. ${ }^{1)}$

Extrapolation of the relations $\log K_{\mathrm{Si}}^{\prime}-[\% \mathrm{Si}]$ obtained for the $\mathrm{Fe}-40 \% \mathrm{Ni}$ alloy to zero silicon content allowed one to determine the equilibrium constant $K_{\mathrm{Si}}$ for the temperatures considered:

$$
\begin{aligned}
\left(\mathrm{SiO}_{2}\right) & =[\mathrm{Si}]+2[\mathrm{O}] \\
K_{\mathrm{Si}} & =\frac{a_{[\mathrm{Si}]} a_{[\mathrm{O}]}^{2}}{a_{\left(\mathrm{SiO}_{2}\right)}}
\end{aligned}
$$

and to obtain equation for the temperature dependence of the equilibrium constant:

$$
\log K_{\mathrm{Si}}=-\frac{23607}{T}+7.610
$$

The $K_{\mathrm{Si}}$ equilibrium constant determined by Eq. (27) at $1873 \mathrm{~K}$ is in good agreement with the data above estimated (Fig. 1).

\subsection{Complex Deoxidation with Manganese and Silicon}

Complex deoxidation with manganese and silicon gives lower concentrations of oxygen in metal due to a decrease in the activities of silica and manganese oxides. The deoxidation of the $\mathrm{Fe}-40 \% \mathrm{Ni}$ alloy with silicon has been studied experimentally at the manganese content in melt equal to $0.05-0.06,0.10-0.12,0.20-0.22$, and $0.48-0.51 \%$ at $1873 \mathrm{~K}$. The results obtained are given in Fig. 5. As is seen from these data, the manganese-silicon complex deoxidation enables one to obtain the lower oxygen concentrations than silicon deoxidation and the considerably less contents than manganese deoxidation. Dependence of oxygen concentrations in melt on the silicon content for each manganese concentrations range can be described by the following empirical equations:

$$
\begin{aligned}
& 0.05-0.06 \% \mathrm{Mn} \text { and } 0.02-0.19 \% \mathrm{Si} \\
& \log [\% \mathrm{O}]=-2.77+1.05[\% \mathrm{Si}]-0.61 \log [\% \mathrm{Si}] . . \\
& 0.10-0.12 \% \mathrm{Mn} \text { and } 0.01-0.22 \% \mathrm{Si} \\
& \log [\% \mathrm{O}]=-2.77+0.94[\% \mathrm{Si}]-0.57 \log [\% \mathrm{Si}] . .
\end{aligned}
$$

$0.20-0.22 \% \mathrm{Mn}$ and $0.02-0.50 \% \mathrm{Si}$

$$
\log [\% \mathrm{O}]=-2.75+0.51[\% \mathrm{Si}]-0.52 \log [\% \mathrm{Si}]
$$

$0.48-0.51 \% \mathrm{Mn}$ and $0.05-1.41 \% \mathrm{Si}$

$$
\log [\% \mathrm{O}]=-2.67+0.04[\% \mathrm{Si}]-0.43 \log [\% \mathrm{Si}]
$$

The region of silica-saturated silicates $\left(a_{\mathrm{SiO}_{2}}=1\right)$ is bound by curve 1 (Fig. 5), which corresponds to Eq. (22). These results agree with those of combined deoxidation of ironbased melts with manganese and silicon. ${ }^{13)}$ Solving Eqs.

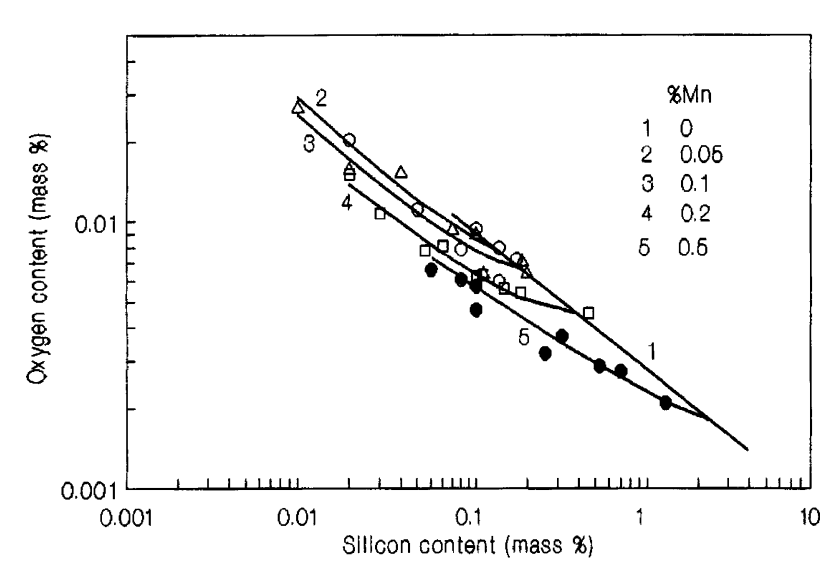

Fig. 5. Dependence of oxygen content in the $\mathrm{Fe}-40 \% \mathrm{Ni}$ melt on the contents of Mn and Si at $1873 \mathrm{~K}$.

(28) to (31) and (22) together, one can determine the content of silicon ([Si]*) corresponding to the deoxidation products saturated with silica at $1873 \mathrm{~K}$ for the given manganese content in the $\mathrm{Fe}-40 \% \mathrm{Ni}$ melt:

$$
\begin{array}{lcccc}
{[\mathrm{Mn}], \%} & 0.05-0.06 & 0.10-0.12 & 0.20-0.22 & 0.48-0.51 \\
{[\mathrm{Si}]^{*}, \%} & 0.15 & 0.20 & 0.43 & 2.63
\end{array}
$$

The results obtained can be described by the following equation:

$$
\log [\% \mathrm{Si}] *=-0.96+2.78[\% \mathrm{Mn}]
$$

Solving this equation for $[\mathrm{Mn}]=0$, we obtain $[\% \mathrm{Si}]^{*}=$ $0.11 \%$, which agrees with the above given results of deoxidation of the $\mathrm{Fe}-40 \% \mathrm{Ni}$ melt only with silicon. When deoxidized with couple of manganese and silicon, they are in the equilibrium with the deoxidation products:

$$
\begin{array}{r}
\left(\mathrm{SiO}_{2}\right)+2[\mathrm{Mn}]=2(\mathrm{MnO})+[\mathrm{Si}] \\
K_{(33)}=\frac{a_{\mathrm{MnO}}^{2} a_{[\mathrm{Si}]}}{a_{\mathrm{SiO}_{2}} a_{\mathrm{Mn}}^{2}} \ldots \ldots \ldots . . .
\end{array}
$$

The activities of manganese oxide and silica in the deoxidation products can be calculated by the following formulas $^{14) \text {. }}$

$$
\begin{aligned}
& a_{\mathrm{MnO}}=[\% \mathrm{O}]_{\mathrm{MnSi}} /[\% \mathrm{O}]_{\mathrm{Mn}} \text { at the same }[\% \mathrm{Mn}] \\
& a_{\mathrm{SiO}_{2}}=[\% \mathrm{O}]_{\mathrm{MnSi}}^{2} /[\% \mathrm{O}]_{\mathrm{Si}}^{2} \text { at the same }[\% \mathrm{Si}] \ldots . . .
\end{aligned}
$$

These activities estimated by Eqs. (35) and (36), are given in Table 2. This calculation performed for $0.20 \% \mathrm{Mn}$ and $0.01-0.43 \% \mathrm{Si}$ in melt. Oxygen concentrations for the melts deoxidized with manganese $\left([\mathrm{O}]_{\mathrm{Mn}}\right)$ were estimated by Eq. (16), for the melts deoxidized with silicon $\left([\mathrm{O}]_{\mathrm{Si}}\right)$ by Eq. (22), and for the melts deoxidized with manganese and silicon $\left([\mathrm{O}]_{\mathrm{MnSi}}\right)$ by Eq. (30).

Dependencies of $\mathrm{MnO}$ and $\mathrm{SiO}_{2}$ activities in the $\mathrm{MnO}-$ $\mathrm{SiO}_{2}$ melt on their mole fractions reported by Abraham et $a l .{ }^{15)}$ are given in Fig. 6. If it is assumed that $\mathrm{MnO}$ and $\mathrm{SiO}_{2}$ were only present in the oxide phase during our experiments on manganese and silicon deoxidation, then, by plotting the estimated values of the $\mathrm{SiO}_{2}$ activity (Table 2) on the line obtained in previous work, ${ }^{15}$ ) it is possible to determine the $\mathrm{MnO}$ and $\mathrm{SiO}_{2}$ mole fractions in the oxide phase (Table 3). The obtained dependence of the MnO activity on 
ISIJ International, Vol. 43 (2003), No. 10

Table 2. Calculated activities of silica and manganese oxide for the combined deoxidation of the $\mathrm{Fe}-40 \% \mathrm{Ni}$ alloy with manganese and silicon at $1873 \mathrm{~K}$

\begin{tabular}{|c|c|c|c|c|c|c|c|}
\hline$[\mathrm{Si}], \%$ & $\begin{array}{c}{[\mathrm{O}]_{\mathrm{Si}} \%} \\
\text { Eq. (22) }\end{array}$ & {$[\mathrm{Mn}], \%$} & $\begin{array}{c}{[\mathrm{O}]_{\mathrm{Mn}}, \%} \\
{[\mathrm{O}]_{\mathrm{MnSi}}, \%}\end{array}$ & $a_{\mathrm{SiO}_{2}}$ & $a_{\mathrm{MnO}}$ & $K_{(33)}^{\prime}$ \\
\hline 0.01 & 0.0700 & 0.20 & 0.0192 & 0.0197 & 0.079 & 0.990 & 3.102 \\
\hline 0.02 & 0.0320 & 0.20 & 0.0192 & 0.0140 & 0.191 & 0.704 & 0.704 \\
\hline 0.05 & 0.01348 & 0.20 & 0.0192 & 0.00895 & 0.441 & 0.449 & 0.572 \\
\hline 0.07 & 0.01136 & 0.20 & 0.0192 & 0.00770 & 0.459 & 0.387 & 0.569 \\
\hline 0.10 & 0.00948 & 0.20 & 0.0192 & 0.00662 & 0.488 & 0.332 & 0.566 \\
\hline 0.20 & 0.00667 & 0.20 & 0.0192 & 0.00519 & 0.606 & 0.261 & 0.560 \\
\hline 0.30 & 0.00543 & 0.20 & 0.0192 & 0.00473 & 0.759 & 0.237 & 0.557 \\
\hline 0.43 & 0.00458 & 0.20 & 0.0192 & 0.00458 & 1.0 & 0.230 & 0.555 \\
\hline
\end{tabular}

Table 3. Calculated values of $\mathrm{SiO}_{2}$ and $\mathrm{MnO}$ mole fractions in oxide phase.

\begin{tabular}{|c|c|c|c|c|c|}
\hline$a_{\mathrm{SiO}_{2}}$ & $a_{\mathrm{MnO}}$ & $X_{\mathrm{SiO}_{2}}$ & $X_{\mathrm{MnO}}$ & $\left(\mathrm{SiO}_{2}\right), \%$ & $(\mathrm{MnO}), \%$ \\
\hline 0.079 & 0.990 & 0.740 & 0.260 & 22.89 & 77.11 \\
\hline 0.191 & 0.704 & 0.670 & 0.330 & 29.39 & 70.61 \\
\hline 0.441 & 0.449 & 0.588 & 0.412 & 37.19 & 62.81 \\
\hline 0.459 & 0.387 & 0.583 & 0.417 & 37.67 & 62.33 \\
\hline 0.488 & 0.332 & 0.578 & 0.422 & 38.16 & 61.84 \\
\hline 0.606 & 0.261 & 0.550 & 0.450 & 40.88 & 59.12 \\
\hline 0.758 & 0.237 & 0.521 & 0.479 & 43.72 & 56.28 \\
\hline 1.0 & 0.230 & 0.490 & 0.510 & 46.80 & 53.20 \\
\hline
\end{tabular}

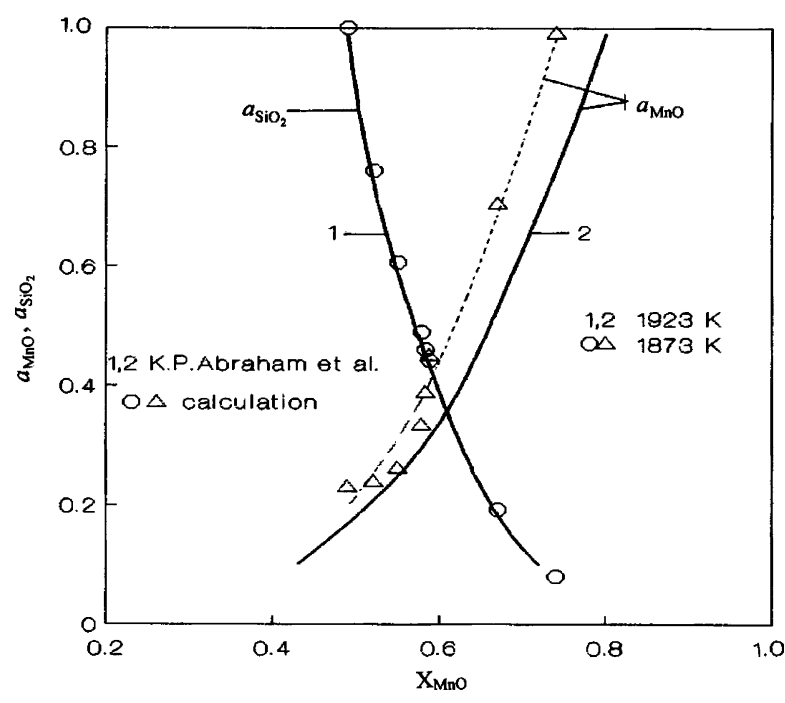

Fig. 6. Activities of $\mathrm{MnO}$ and $\mathrm{SiO}_{2}$ in the $\mathrm{MnO}-\mathrm{SiO}_{2}$ melt

the mole fraction (Table 3) is shown in Fig. 6 by dotted curve. As is seen from Fig. 6, the dependence obtained in the present study agrees satisfactorily with the reported one. ${ }^{15)}$ Small discrepancy seems to be caused by small amounts of $\mathrm{Al}_{2} \mathrm{O}_{3}$ dissolved from $\mathrm{Al}_{2} \mathrm{O}_{3}$ crucibles at the experiment.
The values of $K_{(33)}^{\prime}$ given in Table 2 were calculated by the following equation:

$$
K_{(33)}^{\prime}=\frac{a_{\mathrm{MnO}}^{2}[\% \mathrm{Si}]}{a_{\mathrm{SiO}_{2}}[\% \mathrm{Mn}]^{2}}
$$

Calculating $K_{(33)}^{\prime}$ and assuming that activity coefficients of manganese oxide and silica calculated at $[\mathrm{Mn}]=0.2 \%$ are available at different manganese and silicon contents in melt, it is possible to evaluate the silicon content by Eq. (37) and the oxygen concentration in the melts deoxidized with silicon and a couple of silicon and manganese by Eqs. (22) and (36), respectively. Calculation has been performed for manganese concentrations of $0.1,0.3,0.4$ and $0.5 \%$. Dependence of the oxygen concentration on contents of silicon and manganese in melt at $1873 \mathrm{~K}$ can be written in the form of the following empirical equations:

$$
\begin{aligned}
& \text { at }[\mathrm{Mn}]=0.1 \% \\
& \log [\% \mathrm{O}]=-2.75+2.33[\% \mathrm{Si}]-0.52 \log [\% \mathrm{Si}] \text {. } \\
& \text { at }[\mathrm{Mn}]=0.3 \% \\
& \log [\% \mathrm{O}]=-2.75+0.23[\% \mathrm{Si}]-0.52 \log [\% \mathrm{Si}] \\
& \text { at }[\mathrm{Mn}]=0.4 \% \\
& \log [\% \mathrm{O}]=-2.75+0.13[\% \mathrm{Si}]-0.52 \log [\% \mathrm{Si}]
\end{aligned}
$$




$$
\begin{aligned}
& \text { at }[\mathrm{Mn}]=0.5 \% \\
& \qquad \log [\% \mathrm{O}]=-2.75+0.082[\% \mathrm{Si}]-0.52 \log [\% \mathrm{Si}]
\end{aligned}
$$

The obtained dependencies are in good agreement with similar results calculated on the basis of experimental data (Eqs. (29) and (31)). Figure 7 shows the dependence of oxygen concentration on the contents of silicon and manganese in melt at $1873 \mathrm{~K}$. The joint solution of Eqs. (30), (38)-(41) and (22) allowed one to evaluate the content of silicon $\left([\mathrm{Si}]^{*}\right)$ when deoxidation products are saturated with silica:

$$
\begin{array}{lccccc}
{[\mathrm{Mn}], \%} & 0.1 & 0.2 & 0.3 & 0.4 & 0.5 \\
{[\mathrm{Si}]^{*}, \%} & 0.105 & 0.430 & 0.945 & 1.680 & 2.625
\end{array}
$$

The obtained data can be empirically written as:

$$
\log [\% \mathrm{Si}]^{*}=-1.167+3.398[\% \mathrm{Mn}]
$$

If $[\mathrm{Mn}]=0$, then $[\mathrm{Si}]=0.07 \%$, which agrees with that calculated by Eq. (32).

It is also possible to calculate the corresponding manganese contents for a given silicon contents by Eq. (37) when silica saturated oxide phase $\left(a_{\mathrm{SiO}_{2}}=1\right)$ is formed. In this case, Eq. (37) can be revised to Eq. (43)

$$
[\% \mathrm{Mn}]=a_{\mathrm{MnO}}^{\circ}([\% \mathrm{Si}] / 0.555)^{1 / 2}
$$

where $a_{\mathrm{MnO}}^{\circ}$ represents the activity of manganese monoxide in the silica-saturated oxide phase at $1873 \mathrm{~K}$, which equals to 0.230 (Table 2). The relations of residual manganese and silicon contents for the boundary of immiscibility region in the $\mathrm{MnO}-\mathrm{SiO}_{2}$ system at $1873 \mathrm{~K}$ are represented below and in Fig. 8:

$\begin{array}{lcccccccc}{[\mathrm{Si}], \%} & 0.05 & 0.1 & 0.2 & 0.5 & 1.0 & 2.0 & 3.0 & 5.0 \\ {[\mathrm{Mn}], \%} & 0.069 & 0.098 & 0.138 & 0.218 & 0.309 & 0.436 & 0.535 & 0.690 \\ {[\% \mathrm{Mn}] /[\% \mathrm{Si}]} & 1.380 & 0.976 & 0.690 & 0.436 & 0.309 & 0.218 & 0.178 & 0.138\end{array}$

It is seen from the data shown that the high $[\% \mathrm{Mn}] /[\% \mathrm{Si}]$ ratios are necessary when silicon residual contents are rather low, namely, not above $0.05 \%$, i.e. when the loss of deoxidizers is high. At low losses (low degree of oxidation in melt), it is not necessary to have the high $[\% \mathrm{Mn}] /[\% \mathrm{Si}]$ ratio. The oxide phase containing a large amount of manganese oxide is inexpedient because of the high melting point of manganese oxide $(2058 \mathrm{~K})$; at $\mathrm{MnO}>80 \%$ the solid phase is formed in the $\mathrm{MnO}-\mathrm{SiO}_{2}$ system. ${ }^{14)}$ Super high $[\% \mathrm{Mn}] /[\% \mathrm{Si}]$ ratio can be calculated by Eq. (37), above these ratios the deoxidation product contains solid manganese oxide. As shown above, in the case of $a_{\mathrm{MnO}}=0.99, a_{\mathrm{SiO}_{2}}=0.079$, and $K_{(32)}^{\prime}=3.102$ (Table 2), Eq. (37) is revised as follows:

$$
[\% \mathrm{Mn}]=2.00([\% \mathrm{Si}])^{1 / 2}
$$

The results calculated by this equation at $1873 \mathrm{~K}$ are shown below:

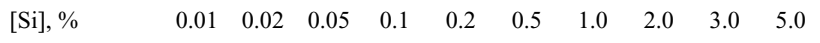

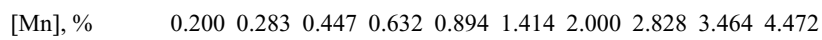

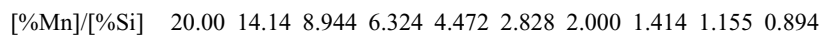

On condition that the liquid products of deoxidation should be obtained as a result of deoxidation of the $\mathrm{Fe}-40 \%$ $\mathrm{Ni}$ melt and summarizing the data given above, the region

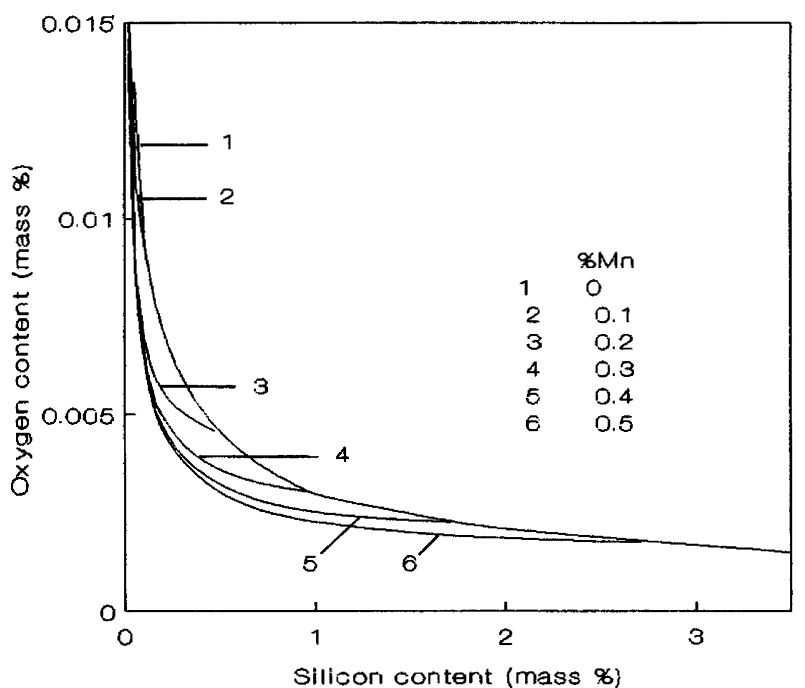

Fig. 7. Oxygen content in the $\mathrm{Fe}-40 \% \mathrm{Ni}$ melt deoxidized with $\mathrm{Mn}$ and $\mathrm{Si}$ at $1873 \mathrm{~K}$.

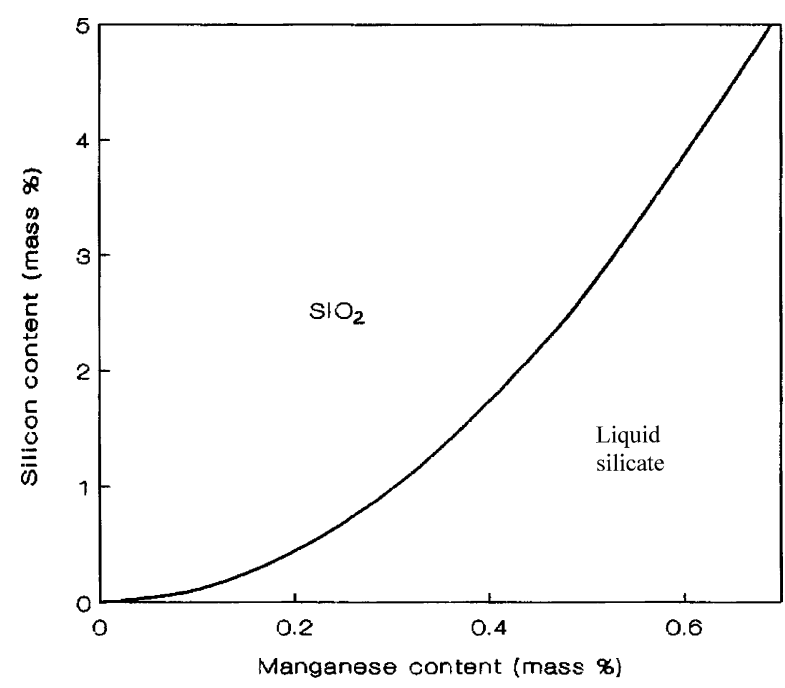

Fig. 8. Boundary of immiscibility region in the $\mathrm{MnO}-\mathrm{SiO}_{2}$ system between solid $\mathrm{SiO}_{2}$ and liquid silicates at $1873 \mathrm{~K}$.

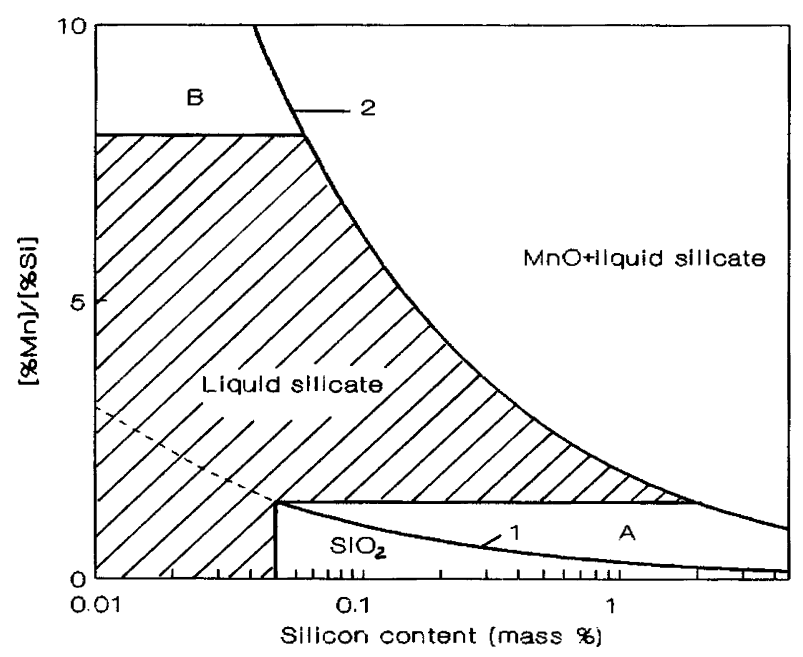

Fig. 9. Regions of solid and liquid products of deoxidation with $\mathrm{Mn}$ and $\mathrm{Si}$ in the $\mathrm{Fe}-40 \% \mathrm{Ni}$ melt at $1873 \mathrm{~K}$.

of solid and liquid products of deoxidation with manganese and silicon at $1873 \mathrm{~K}$ can be determined from the dependence given in Fig. 9. Curve 1 separates manganese sili- 
cates saturated with silica from the silica solid solutions. Curve 2 is a boundary between liquid manganese silicates and the solid solutions based on manganese oxide in the $\mathrm{MnO}-\mathrm{SiO}_{2}$ system. The region between these curves corresponds to liquid manganese silicates in equilibrium with manganese and silicon in metal.

In the left-hand portion of this plot (Fig. 9) the zone (up to $0.05 \% \mathrm{Si}$ ) of liquid silicates (iron silicates mainly) is shown, as the equilibrium oxide phase above the $\mathrm{Fe}-40 \% \mathrm{Ni}$ melt contains $>99 \% \mathrm{FeO}$ and $<1 \% \mathrm{NiO}^{4)}$ In addition, two straight lines in parallel to $X$-axis are drawn in the region of liquid silicates, which divide this region into three portions. These lines are drawn from the viewpoint of deoxidation kinetics. When the complex deoxidizer was used, for example, silico-manganese, processes of dissolution and oxidation proceed simultaneously. Thus, it is most probable to assume that deoxidation rate is controlled by the dissolution and diffusion of deoxidizing agent in a melt. Therefore, manganese and silicon react in amounts directly proportional to their contents in the deoxidizer. So, it is as optimum to assume $[\% \mathrm{Mn}] /[\% \mathrm{Si}]=1.4-8$. Based on the reasons indicated, despite of the amount of manganese alloys added as a deoxidizing agent, the solid reaction products can be in the form of solid inclusions due to low diffusion rates.

Shaded zone (Fig. 9) represents liquid silicates formed after deoxidation with manganese and silicon. Within the region A deoxidation products should be in the liquid state under equilibrium conditions. However, if to consider the deoxidation process from viewpoint of kinetics or choice of deoxidizer composition through the ratio $[\% \mathrm{Mn}] /[\% \mathrm{Si}]$, then, the liquid-solid products will be obtained after deoxidation using alloys with $[\% \mathrm{Mn}] /[\% \mathrm{Si}]$ ratio $<1.4$. To form liquid manganese silicates, manganese should be consumed in amounts than those of silicon by a factor 1.4. Therefore, silicon is first oxidized, being precipitated in the form of solid inclusions and, when $[\% \mathrm{Mn}] /[\% \mathrm{Si}]$ ratio increases, liquid silicates are formed. Formation of solid manganese oxide in the region $\mathrm{B}$ is possible due to the reasons similar to those indicated in the case of A region. With temperature drop, the range of the optimum manganese to silicon ratios in the deoxidizer narrows.

\section{Conclusions}

The thermodynamic analysis of oxygen, manganese and silicon dissolved in Fe-Ni melts has been carried out. The deoxidation power of manganese essentially increases with an increase in the nickel content in melt. The solubility curves pass through the minimum, which shifts to the lower manganese contents with an increase in the nickel concen- tration in melt. For alloys containing more than 50-60\% nickel, the minimum oxygen concentrations are reached at the manganese content in melt equal to $1-1.5 \%$ The further increase in the manganese content causes the increase of oxygen concentration.

The silicon deoxidation power also increases with an increase in the nickel content in melt, but not so sharply, as in the case of manganese. In the considered range of silicon contents, no minimum was observed in the oxygen solubility curves.

Thermodynamics of oxygen solutions in the $\mathrm{Fe}-40 \% \mathrm{Ni}$ melts containing manganese and silicon has been studied experimentally within a temperature range of $1823-$ $1923 \mathrm{~K}$. With temperature drop, the deoxidation power of both manganese and silicon increases. In the $\mathrm{Fe}-40 \% \mathrm{Ni}$ melts, the deoxidation power of manganese and that of silicon are higher than in iron but lower than in nickel. Dependence of oxygen concentration on manganese and silicon contents is described by empirical equations. When complexly deoxidized with manganese and silicon, it is possible to obtain the lower oxygen concentrations in metal, in comparison with the individual deoxidation, due to the decrease in the activities of manganese oxide and silica in the oxide phase.

\section{Acknowledgments}

We thank the managing officers of Sumitomo Metal Industries Ltd. for support in the research performance.

\section{REFERENCES}

1) I. S. Kulikov: Deoxidation of Alloys, Metallurgija, Moscow, (1975), 504.

2) Steelmaking Data Soucebook: Gordon \& Breach Science Publ, N.Y.Tokyo, (1988), 325.

3) G. K. Sigworth, J. F. Elliott, G. Vaughn and G. H. Geiger: Met. Soc. CIM, Ann. V. (1977), 104.

4) V. Ya. Dashevskii, N. N. Makarova, K. V. Grigorovitch and V. I. Kashin: Dokl. Akad. Nauk, 357 (1997), 789.

5) E. T. Turkdogan: Physical Chemistry of High Temperature Technology, Academic Press, NY, (1980), 344.

6) F. Ishii and S. Ban-ya: Tetsu-to-Hagané, 81 (1995), 22.

7) M. G. Frohberg and M. Wang: Z. Metallkd., 81 (1990), 513.

8) S. Ban-ya and F. Ishii: ISIJ Int., 34 (1994), 484.

9) T. Chiang and Y. A. Chang: Metall. Trans., 7B (1976), 453.

10) V. Ya. Dashevskii, A. M. Katsnelson, N. N. Makarova and V. I. Kashin: Metall, 5 (1996), 3.

11) W. A. Fischer and H. J. Fleischer: Arch. Eisenhüttenwes., 32 (1961), 1 .

12) M. I. Gasik: Manganese, Metallurgija, Moscow, (1992), 607.

13) E. T. Turkdogan: Chemical Metallurgy of Iron and Steel, Symposium 1971, ISI, London, (1973), 153.

14) I. S. Kulikov and A. M. Samarin: Izv. Akad. Sc. USSR. OTN, 10 (1954), 23.

15) K. P. Abraham, M. W. Davies and F. D. Richardson: J. Iron Steel Inst., 196 (1960), 82 